\title{
Peningkatan hasil belajar siswa dalam pembelajaran ilmu pengetahuan alam dengan pendekatan keterampilan proses di sekolah dasar
}

\author{
Vivi Mairina $^{\left.1^{*}\right)}$, Firman Firman $^{2}$, Desyandri Desyandri ${ }^{3}$ \\ ${ }^{123}$ Universitas Negeri Padang
}

\begin{tabular}{l} 
Article Info \\
\hline Article history: \\
Received Jan $30^{\text {th }}, 2021$ \\
Revised Feb $13^{\text {th }}, 2021$ \\
Accepted Feb $19^{\text {th }}, 2021$
\end{tabular}

\section{Keyword:}

Hasil belajar

Ilmu pengetahuan alam

Pendekatan keterampilan proses

\section{Corresponding Author:}

Vivi Mairina,

Universitas Negeri Padang

Email: vivijundrial@gmail.com

\begin{abstract}
ABSTRAK
Pendekatan Keterampilan Proses bertujuan untuk membuat siswa termotivasi untuk belajar IPA. Tujuan penelitian ini adalah mendeskripsikan perencanaan, pelaksanaan, dan hasil belajar siswa dalam pembelajaran IPA dengan pedekatan keterampilan proses. Subyek dalam penelitian ini adalah siswa kelas IV SDN 08 Sungai Rumbai yang berjumlah 34 orang, terdiri dari 14 orang laki- laki dan 20 orang perempuan. Jenis penelitian ini adalah penelitian tindakan kelas dengan menggunakan pendekatan kualitatif dan kuantitatif. Dari hasil penelitian dengan pendekatan keterampilan proses Aspek kognitif siswa memperoleh nilai 90, pada spek afektif siswa adalah $78 \%$, dan pada aspek psikomotor adalah $84 \%$. Dapat disimpulkan bahwa Pembelajaran IPA dengan pendekatan keterampilan proses dapat meningkatkan hasil belajar siswa kelas IV SDN 08 Sungai Rumbai.
\end{abstract}

C 2021 The Authors. Published by IICET

This is an open access article under the CC BY-NC-SA license (https://creativecommons.org/licenses/by-nc-sa/4.0

\section{Pendahuluan}

Pembelajaran IPA di SD merupakan salah satu pembelajaran yang tergolong penting pada jenjang pendidikan sadar. Dijelaskan oleh (Fitriyati, Hidayat and Munzil, 2017) Ilmu pengetahuan alam (IPA) adalah ilmu yang mempelajari mengenai gejala alam berupa fakta, konsep dan hukum yang telah teruji kebenarannya berdasarkan sebuah penelitian. Depdiknas (Fitria, 2017) menjelaskan bahwa pendidikan IPA dapat menjadi wahana bagi siswa untuk mempelajari diri sendiri dan alam sekitar, serta prospek pengembangan lebih lanjut dalam menerapkannya di dalam kehidupan sehari-hari. Menurut (Hasibuan, 2018) Tujuan mempelajari IPA di SD, agar siswa dapat menggunakan metode ilmiah untuk menyelesaikan persoalan alam, sehingga IPA bukan hanya penguasaan kumpulan pengetahuan fakta, konsep atau prinsip saja melainkan berupa proses penemuan.

Berdasarkan hasil ujian semester I dengan Kriteria Ketuntasan Minimum (KKM) 70 hanya memperoleh persentase keberhasilan siswa $41 \%$ yang berada pada kategori kurang. rendahnya persentase keberhasilan siswa. Masalah ini juga disebabkan oleh guru yang karena kurang variasi dalam pembelajaran. Guru sudah memberikan materi pelajaran melalui media pembelajaran, namun pendekatan yang digunakan masih konvensional, sehingga peserta didik terlihat bosan dan jenuh.

Berdasarkan hasil pengamatan guru pada proses pembelajaran IPA Kelas IV SDN 08 Sungai Rumbai masih rendahnya persentase keberhasilan siswa. Masalah ini juga disebabkan oleh guru yang karena kurang 
variasi dalam pembelajaran. Guru sudah memberikan materi pelajaran melalui media pembelajaran, namun pendekatan yang digunakan masih konvensional, sehingga peserta didik terlihat bosan dan jenuh.

Agar proses pembelajaran IPA menjadi lebih bermakna bagi siswa, maka guru sebaiknya menggunakan pendekatan yang cocok dalam pembelajaran, supaya siswa termotivasi dalam proses pembelajaran. Menurut (Gulo, 2018) Salah satu pendekatan yang dapat dilakukan untuk membuat siswa termotivasi untuk belajar IPA adalah dengan PKP karena keterampilan proses mencerminkan komunikasi multi arah dalam pembelajaran dan siswa bisa mendapatkan informasi sesuai dengan perkembangan kemampuan mental, fisik dan penampilan. Di dalam (V, 2018)dijelaskan bahwa pendekatan keterampilan proses ini memberikan kesempatan kepada siswa untuk memperlihatkan unjuk kerja melalui sejumlah keterampilan dan siswa dituntut untuk berpikir kritis, objektif serta menyatakan pendapat setelah mereka mengamati objek tertentu dalam menghadapi kenyataan di alam.

Ahmad (Naziaha, Maula and Sutisnawati, 2020) menyatakan bahwa didalam setiap proses pembelajaran keaktifan belajar merupakan suatu hal yang sangat berperan penting. Menurut (Di and Dasar, 2019) setiap orang yang belajar harus aktif sendiri dan tanpa adanya aktivitas maka proses pembelajaran tidak mungkin terjadi. Melalui daya keaktifan dari peserta didik didalam proses pembelajaran, sehingga dalam mengikuti kegiatan Proses Belajar Mengajar (PBM) peserta didik akan lebih cenderung memiliki rasa ketertarikan dan semangat yang tinggi.

Penelitian menggunakan pendekatan keterampilan proses untuk meningkatkan hasil belajar siswa pada pembelajaran IPA ini pernah dilakukan oleh (V, 2018) Erva Viyanti dkk dengan judul "Pengaruh Penggunaan Keterampilan Proses Terhadap Hasil Belajar Materi Tumbuhan Hijau di Kelas" yang menunjukan hasil terdapat pengaruh yang signifikan dalam penggunaan pendekatan keterampilan proses terhadap hasil belajar materi tumbuhan hijau di kelas V. Merujuk dari permasalahan dan hasil penelitian di atas, penulis bermaksud melakukan sebuah penelitian dengan judul "Peningkatan Hasil Belajar Siswa dalam Pembelajaran IPA dengan Pendekatan Keterampilan Proses di SD

\section{Metode}

Penelitian ini dilaksanakan di SDN 08 Sungai Rumbai dengan subjek pada penelitian ini yaitu siswa kelas IV yang berjumlah 34 orang, 14 orang laki- laki dan 20 orang perempuan. Penelitian ini dimulai dari tanggal 16 s/d 23 bulan April 2020 yaitu di semester 2 TA 2019/ 2020 dijelaskan bahwa pengambilan sampel berdasarkan pada subjeknya, jika kurang dari 100 orang maka diambil semua subjek, jika besar atau lebih dari 100 orang maka diambil $10-15 \%$ atau $20-25 \%$ atau lebih. Berdasarkan pendapat ahli di atas maka sampelpada penelitian ini semua siswa kelasV.3 SDN 08 Sungai Rumbai. Teknik pengambilan sampel pada penelitian ini menggunakan teknik probability sampling, yaitu teknik pengambilan sampel yang memberikan peluang yang sama bagi setiap unsur (anggota) populasi untuk dipilih sebagai anggota. (Retnawati, 2015)

Jenis penelitian ini adalah penelitian tindakan kelas (Classroom Action Research) melalui pendekatan kualitatif dan kuantitatif. Menurut (Sanjaya, 2016) pelaksanaan penelitian tindakan dimulai dari munculnya masalah menyiapkan perencanaan, melaksanakan tindakan, observasi, mengadakan refleksi, melakukan rencana ulang, melaksanakan tindakan, dan seterusnya yang dilakukan dalam bentuk Spiral. Dimulai dari tahap perencanaan, pelaksanaan, pengamatan, dan refleksi. Teknik analisis data yang digunakan dalam penelitian ini adalah data kuantitatif dan kualitatif. Data kuantitatif diperoleh dari hasil tes siswa dan data kualitatif diperoleh dari observasi, catatan guru, dan wawancara.

\section{Hasil dan Pembahasan}

\section{Siklus I Pertemuan 1}

Penggunaan Pendekatan Keterampilan Proses dalam pembelajaran IPA dengan kompetensi dasar menyimpulkan hasil percobaan bahwa gaya (dorongan dan tarikan) dapat mengubah gerak suatu benda disusun dalam bentuk rencana pembelajaran (RPP). Sesuai dengan kompetensi dasar yang telah dianalisis, indikator yang diharapkan tercapai dalam pembelajaran pada pertemuan 1 adalah: (1) menjelaskan pengertian gaya, (2) menyebutkan bentuk gaya, (3) menjelaskan bentuk gaya yang berupa dorongan, (4) menjelaskan bahwa gaya dorong dapat mengubah gerak benda, dan (5) membuktikan bahwa gaya dorong menghasilkan 4 macam gerak benda.

Tujuan pembelajaran yang akan dicapai pada pertemuan 1 adalah : (1) melalui pengamatan tentang gaya, siswa dapat mejelaskan pengertian gaya dengan benar, (2) melalui percobaan tetang gaya, siswa dapat menyebutkan bentuk gaya dengan benar, (3) berdasarkan percobaan tentang gaya, siswa dapat mencontohkan 
gaya dorong dengan benar, (4) dengan melakukan percobaan tentang gaya, siswa dapat menjelaskan gaya dorong dapat merobah gerak benda dengan benar, dan (5) melalui pengamatan tentang gaya, siswa dapat membuktikan bahwa gaya dorong menghasilkan 4 macam gerak benda dengan benar.

Pertemuan I ini dilaksanakan pada tanggal 16 April 2020 selama 2 jam pembelajaran dari pukul 07.30 8.40 WIB. Proses pelaksanaan tindakan pada pertemuan pertama difokuskan pada materi pembelajaran gaya dorong dapat mengubah gerak dan bentuk benda.

Pengamatan RPP dilakukan oleh observer, dari hasil pengamatan tersebut deskriptor yang belum terlaksana dalam RPP adalah pemilihan materi ajar masih kurang sesuai dengan karakteristik siswa, cakupan materi yang diajarkan guru masih dinilai sempit dan tidak sistematis, pemilihan sumber dan media pembelajaran belum sesuai dengan karakter siswa, langkah pembelajaran sesuai dengan alokasi waktu dan disampaikan jelas dan rinci; dan pedoman penskoran soal belum ada. Sehingga penilaian RPP memperoleh nilai $68 \%$ dengan kualifikasi cukup. pada aktivitas guru deskriptor yang belum muncul adalah kelompok belum dibagi sesuai dengan kemampuan siswa, belum menyebutkan tata tertib dan cara melakukan percobaan, belum memberikan waktu yang cukup. Sehingga dari pengamatan tersebut aktivitas guru memperoleh nilai $63 \%$ dan Pada aktivitas siswa yang belum muncul adalah siswa kurang mendengarkan penjelasan guru, tidak mengerti dalam pengisian LKS. Dalam melakukan percobaan siswa kurang memahami langkah-langkah dalam melaksanakan percobaan. Berdasarkan hasil pengamatan tersebut, maka aktivitas siswa memperoleh nilai $63 \%$. Hasil pembelajaran yang diperoleh siswa pada pelaksanaan tindakan penggunaan metode eksperimen dalam pembelajaran IPA pada aspek kognitif adalah 63 dengan kualifikasi cukup. Pada aspek afektif diperoleh nilai 55\%, dan pada aspek psikomotor memperoleh nilai 55\%.

Berdasarkan hasil pengamatan tersebut, maka untuk pertemuan selanjutnya guru perlu memperhatikan hal-hal berikut: (a) melengkapi tujuan pembelajaran dengan unsur A,B,C, dan D; (b) Memilih materi ajar lebih teliti lagi dan disesuaikan dengan lingkungan siswa; (c) sesuaikan materi dengan alokasi waktu dan perkembangan terakhir dalam bidangnya; (d) Memilih sumber dan media pembelajaran yang sesuai dengan karakteristik siswa dan lingkuang siswa; (e)Langkah-langkah pembelajaran harus jelas dan rinci; (f) Mempersiapkan soal yang sesuai dengan lingkungan sekolah dan lingkungan siswa.

Pada aspek guru yang perlu ditingkatkan adalah hal-hal berikut: (1) guru sebaiknya menetapkan benda yang yang akan diamati dalam praktek gaya dan menentukan langkah-langkah pembelajaran. (2) guru sebaiknya mengelompokkan macam-macam gaya yang bekerja pada suatu benda. (3) guru sebaiknya menugaskan siswa mengukur jarak bola yang ditendang dengan kaki dari tempat semula. (4) guru harus memprediksikan besarnya gaya dorong untuk sebuah benda yang berat. (5) guru harus mengajukan pertanyaan dan respon. (6) guru sebaiknya membuat kesimpulan hasil percobaan tentang gaya gesek dan membuat kesimpulan hasil percobaan tentang gaya mempengaruhi gerak benda

Pada aspek siswa, pada pertemuan berikutnya guru perlu memperhatikan hal-hal berikut: (1) siswa sebaiknya memperhatikan penjelasan guru tentang gaya dan menyiapkan benda-benda yang akan diamati. (2) siswa sebaiknya menentukan perbedaan benda. (3) siswa harus mengukur jarak bla yang ditendang dengan kaki dari tempat semula. (4) siswa harus memprediksi gaya pada benda yang ada di dalam air. (5) siswa seharusnya mengajukan pertanyaan dan respon. (6) siswa sebaiknya membuat kesimpulan hasil percobaan tentang gaya merubah gerak benda dan membuat kesimpulan hasil percobaan tentang pengaruh gaya terhadap benda di dalam air.

Secara keseluruhan hasil belajar siswa pada siklus I pertemuan 1 ini masih belum mencapai target yang diharapkan, sehingga perlu diadakan tindakan perbaikan dan dilanjutkan pada pertemuan selanjutnya. Dalam penyusunan RPP siklus I pertemuan 2 peneliti mengambil materi tentang gaya tarik, dengan indikator pembelajaran terdiri dari: (1) menjelaskan bentuk gaya yang berupa tarikan, (2) membuktikan bahwa gaya tarik menghasilkan 4 macam gerak benda, dan (3) mengidentifikasi erbagai gerakan benda yang diberi gaya. Tujuan pembelajaran yang harus dicapai siswa untuk pertemuan 2 adalah : melalui percobaan siswa dapat menjelaskan bentuk gaya yang berupa tarikan dengan benar, (2) melalui pengamatan siswa dapat mengklasifikasika bahwa gaya tarik menghasilkan 4 macam gerak benda dengan benar, dan (3) dengan percobaan siswa dapat mengidentifikasi berbagai geraka benda yang diberi haya dengan benar.

\section{Siklus II Pertemuan 1}

Pelaksanaan pembelajaran pada pertemuan II ini dilaksanakan pada tanggal 19 April 2020 selama 2 jam pembelajaran. Proses pelaksanaan tindakan pada pertemuan II merupakan lanjutan dari pertemuan I. Pada pertemuan kedua materi pelajaran difokuskan pada gaya tarik. Pelaksanaan pembelajaran menggunakan langkah-langkan pendekatan keterampilan proses. Pelaksanaan tindakan terdiri dari kegiatan awal, inti, dan akhir. 
Pada pertemuan 2 instrumen penilaian RPP diperoleh persentase $75 \%$ dengan kualifikasi baik (B). Pada aspek guru persentase kegiatan guru $71 \%$ dengan kualifikasi baik (B). Pada aktivitas siswa memperoleh nilai $71 \%$ (B), Hasil belajar pada aspek kognitif diperoleh adalah 75, pada aspek afektif adalah $62,5 \%$, Jika dilihat dari rekapitulasi hasil belajar siswa pada siklus I masih menunjukkan bahwa hasil belajar siswa belum mencapai target yang ditetapkan, sehingga perlu diadakan tindakan perbaikan dan dilanjutkan pada siklus II.

Sebelum dilaksanakannya pembelajaran IPA dengan pendekatan keterampilan proses, terlebih dahulu peneliti menyusun rencana pelaksanaan pembelajaran (RPP) pada materi sifat-sifat benda cair. Indikator pembelajaran terdiri dari: (1) menjelaskan perubahan bentuk benda yang disebabkan oleh gaya, (2) menjelaskan perubahan bentuk benda bedasarkan besar kecilnya gaya yang diberikan, (3) membuktikan bahawa gaya dapat merubah bentuk benda.

Pada perencanaan untuk pertemuan selanjutnya guru perlu memperhatikan hal-hal berikut : a) melengkapi tujuan pembelajaran dengan unsur A,B,C, dan D; (b) sesuaikan materi dengan perkembangan terakhir dalam bidangnya; (c) Memilih sumber dan media pembelajaran yang sesuai dengan karakteristik siswa dan lingkungan siswa; (d) Langkah-langkah pembelajaran harus jelas dan rinci; (e) Mempersiapkan soal yang sesuai dengan lingkungan sekolah dan lingkungan siswa.

Pada aktivitas guru untuk pertemuan berikutnya guru perlu memperhatikan hal-hal berikut : (1) guru sebaiknya menentukan perbandingan gaya dan massa benda (2) guru harus menugaskan siswa mengukur berapa lama mobil sampai ke bawah di permukaan yang kasar dan permukaan yang licin. (3) guru sebaiknya memprediksikan besarnya gaya dorong untuk sebuah benda yang ringan. (4) guru sebaiknya mengajukan pertanyaan. (5) guru sebaiknya membuat kesimpulan hasil percobaan tentang gaya gesek dan membuat kesimpulan hasil percobaan tentang gaya mempengaruhi gerak benda.

Pada aktivitas siswa yang harus diperbaiki adalah sebagai berikut : (1) siswa harus menyiapkan bendabenda yang akan diamati, (2) siswa seharusnya mengukur berapa waktu yang diperlukan mobil mainan bergeser pada permukaan yang licin, (3) siswa harus memprediksi gaya merubah bentuk benda dan pada benda yang ada di dalam air, (4) siswa harus mengajukan pertanyaan, (5) siswa sebaiknya membuat kesimpulan hasil percobaan tentang gaya merubah gerak benda dan membuat kesimpulan hasil percobaan tentang pengaruh gaya terhadap benda di dalam air

Jika dilihat dari rekapitulasi hasil belajar siswa pada siklus I masih menunjukkan bahwa hasil belajar siswa belum mencapai target yang ditetapkan, sehingga perlu diadakan tindakan perbaikan dan dilanjutkan pada siklus II.Pertemuan pada siklus II ini dilaksanakan pada tanggal 23 April 2020 selama 2 jam pembelajaran. Proses pelaksanaan tindakan pada pertemuan siklus II difokuskan pada materi pembelajaran gaya dapat mengubah bentuk benda. Dalam pelaksanaan tindakan, penulis berperan sebagai praktisi (guru) dan teman sejawat sebagai observer. Langkah-langkah yang digunakan pada pembelajaran ini menggunakan langkah-langkah pembelajaran dengan menggunakan pendekatan keterampilan proses. Pada kegiatan awal menyiapkan alat, bahan dan media pembelajaran. Menkondisikan fisik kelas dan mengabsen siswa. Membangkitkan skemata siswa dengan memparagakan macam-macam gaya. Menyampaikan tujuan pembelajaran.

Pada kegiatan inti dibagi mejadi tiga yaitu kegiatan ekplorasi, elaborasi, dan konfirmasi. Pada eksplorasi keterampilan mengamati siswa dibagi menjadi 6 kelompok heterogen berdasarkan kemampuan akademiknya. Siswa mengamati gaya yang dilakukan terhadap suatu benda. Siswa mengamati proses terjadinya gaya yang dilakukannya sesuai pengarahan guru. Pada elaborasi dilaksanakan keterampilan mengklasifikasi. Melakukan percobaan untuk menunjukkan perobahan bentuk benda karena adanya gaya. Siswa mengelompokkan bendabenda yang bisa berobah bentuk dengan yang tidak bisa berobah bentuk. Keterampilan memprediksi yaitu meminta siswa meramalkan bentuk benda yang diberi gaya. Pada konfirmasi yang dilaksanakan adalah keterampilan menyimpulkan yaitu menugasi siswa menyimpulkan hasil percobaan tentang gerak /bentuk suatu benda. Keterampilan mengkomunikasikan yaitu menugasi siswa melaporkan hasil percobaan dan ditanggapi oleh kelompok lain. Pada kegiatan akhir menyimpulkan pembelajaran dan melakukan evaluasi terhadap hasil kerja siswa.

Dari hasil penilaian RPP yang belum terlaksana adalah pemilihan materi belum sesuai dengan perkembangan terakhir dalam bidangnya, sehingga diperoleh persentase $89 \%$ dengan kualifikasi baik sekali (BS). Pada aktivitas guru, guru harus memprediksi besarnya gaya bisa merubah bentuk benda, sehingga memperoleh nilai $87 \%$ dengan kualitifikasi sangat baik (SB). Pada aktivitas siswa siswa belum mampu menyimpulkan hasil percobaan dengan benar, sehingga memperoleh nilai 91\% dengan kualifikasi sangat baik (SB). Aspek kognitif siswa memperoleh nilai 90, pada spek afektif siswa adalah $78 \%$, dan pada aspek psikomotor adalah $84 \%$ 
Pada perencanaan perlu memperhatikan hal sebagai berikut: (a) menyusun tujjuan pembelajaran dari yang mudah ke yang sulit; (b) sesuaikan materi dengan perkembangan terakhir dalam bidangnya; (c) Mempersiapkan soal yang sesuai dengan lingkungan sekolah. Pada aktivitas guru perlu memperhatikan halhal berikut: (1) guru sebaiknya menetapkan benda yang bisa berubah dalam praktek gaya (2) guru harus memprediksi besarnya gaya bisa merubah bentuk benda. (3) guru sebaiknya membuat kesimpulan hasil percobaan tentang gaya gravitasi.Pada aktivitas siswa perlu memperhatikan hal-hal berikut : (1) siswa harus memprediksi gaya pada benda di dalam air. (2) siswa sebaiknya membuat kesimpulan hasil percobaan tentang pengaruh gaya terhadap benda di dalam air. Secara keseluruhan hasil belajar siswa, baik kognitif, afektif, dan psikomotor memperoleh hasil yang baik dan memuaskan. Hasil sudah mencapai target yang diharapkan sehingga penelitian ini dapat dikatakan berhasil.

Langkah pembelajaran terdiri atas kegiatan awal, kegiatan inti, kegiatan akhir. Kegiatan awal terdiri atas perencanaan yang mencerminkan persiapan terhadap kondisi kelas secara keseluruhan, membangkitkan skemata siswa, dan penyampaian tujuan pembelajaran. Kegiatan inti rinci dan runtut yang mencerminkankan keterlibatan siswa sebagi subjek dalam pembelajaran IPA dengan menggunakan pendekatan keterampilan proses. Kegiatan akhir terdiri atas refleksi berupa perangkuman materi, motivasi serta tindak lanjut.

Hasil penilaian RPP pertemuan 1 memperoleh persentase $68 \%$ dengan kualifikasi cukup. Sedangkan pada pertemuan 2 memperoleh persentase $75 \%$ dengan kualifikasi baik, jadi rata-rata keberhasilan guru dalam merancang pembelajaran pada siklus I adalah $71,5 \%$ dengan kualifikasi baik. Untuk lebih meningkatkan hasil pada penilaian RPP maka peneliti melanjutkan penelitian ke siklus II. Selanjutnya siklus II pertemuan pertama memperoleh persentase $89 \%$ dengan kualifikasi sangat baik.

Berdasarkan perencanaan yang disusun inti pelaksanaan pembelajaran dilaksanakan sesuai dengan apa yang telah direncanakan, yang mana pada pada penelitian ini terdiri dari dua siklus. Pada siklus I terdiri dari dua pertemuan dan pada siklus II terdiri dari 1 kali pertemuan. Pelaksanaan pembelajaran berdasarkan langkah-langkah pembelajaran dengan menggunakan pendekatan keterampilan proses.

Hasil penilaian kegiatan guru pada pertemuan pertama memperoleh persentase $63 \%$ dan pertemuan kedua memperoleh persentase $71 \%$. Jadi rata-rata penilaian kegiatan guru pada siklus I adalah $67 \%$ dengan kualifikasi cukup. Sedangkan pada siklus II mengalami peningkatan $87 \%$ dengan kualifikasi sangat baik (SB)

Selanjutnya pada penilaian kegiatan siswa pada pertemuan pertama mempe-roleh persentase $63 \%$ dan pada pertemuan kedua memperoleh persentase $71 \%$. Jadi rata-rata penilaian siswa pada siklus I memperoleh persentase $67 \%$ dengan kualifikasi cukup. Sedangkan pada siklus II mengalami peningkatan menjadi 91\% dengan kualifikasi sangat baik (SB).

Pada akhir dari proses pembelajaran IPA maka dihasilkannya sebuah hasil belajar yang telah dicapai oleh siswa. Dalam hasil belajar tersebut dapat dilihat dari tiga aspek yaitu, aspek kognitif, aspek afektif dan, aspek psikomotor. (Sudjana, 2006) menyatakan "hasil belajar adalah perubahan tingkah laku, tingkah laku sebagai hasil belajar dalam pengertian yang luas mencakup bidang kognitif, afektif, dan psikomotoris." Berikut merupakan penjelasan dari hasil pencapaian belajar siswa. Dilihat dari tes akhir persentase nilai rata-rata siswa pada aspek kognitif siklus I memperoleh persentase skor rata-rata 69 mengalami peningkatan pada siklus II adalah 84. Pada aspek afektif siklus I memperoleh persentase skor rata-rata 58,75\% mengalami peningkatan pada siklus II adalah 78,16\%. Sedangkan untuk aspek psikomotor pada siklus I memperoleh persentase skor rata-rata 58,75\% mengalami peningkatan pada siklus II adalah $84 \%$. Berdasarkan nilai tersebut maka pembelajaran IPA dengan pendekatan PKP disimpulkan berhasil karena mencapai target yang ditetapkan yaitu $\geq 85 \%$ siswa mencapai batas KKM yaitu 70. Maka dari itu, penelitian dicukupkan pada siklus II dengan 2 kali pertemuan.

\section{Simpulan}

Berdasarkan pembahasan, ditarik kesimpulan bahwa hasil belajar siswa dalam pembelajaran IPA dapat meningkat dengan menggunakan pendekatan keterampilan proses. Meningkatnya hasil belajar siswa dalam pembelajaran IPA dari siklus I ke Siklus II yaitu 1) Penilaian terhadap RPP dilaksanakan melalui lembar penilaian RPP, dengan hasil pada siklus I pertemuan 1 diperoleh $68 \%$, pada pertemuan 2 diperoleh $75 \%$ sehingga rata-rata siklus I adalah $71,5 \%$ dengan kualifikasi baik (B). Sedangkan pada siklus II diperoleh $89 \%$ dengan kualifikasi sangat baik (SB), 2) Peningkatan hasil belajar dapat dilihat dari hasil pembelajaran siswa yang didapat baik itu dari penilaian proses maupun penilaian hasil ternyata juga lebih baik. Dilihat dari tes akhir persentase nilai rata-rata siswa pada aspek kognitif siklus I memperoleh persentase skor rata-rata 69 mengalami peningkatan pada siklus II adalah 84. Pada aspek afektif siklus I memperoleh persentase skor ratarata 58,75\% mengalami peningkatan pada siklus II adalah 78,16\%. Sedangkan untuk aspek psikomotor pada 
siklus I memperoleh persentase skor rata-rata 58,75\% mengalami peningkatan pada siklus II adalah $84 \%$, 5) pembelajaran IPA dengan pendekatan PKP disimpulkan berhasil karena mencapai target yang ditetapkan yaitu $\geq 85 \%$ siswa mencapai batas KKM yaitu 70

Berdasarkan kesimpulan yang diperoleh dari penelitian ini maka peneliti mengajukan beberapa saran yaitu: (1) Selama pembelajaran berlangsung diharapkan pendidik dapat memberikan media yang tepat dalam memberikan materi agar siswa lebih bersemangat dan mudah dipahami, (2) Penulis berharap pada penelitian lanjutan dapat menggunakan media pembelajaran dengan bentuk lain sesuai dengan.

\section{Referensi}

Di, T. and Dasar, S. (2019) 'Model problem based learning, aktivitas dan hasil belajar', (January).

Fitria, Y. (2017) 'Efektivitas Capaian Kompetensi Belajar Siswa Dalam Pembelajaran Sains Di Sekolah Dasar', Jurnal Inovasi Pendidikan Dan Pembelajaran Sekolah Dasar, 1(2). doi: 10.24036/jippsd.v1i2.8605.

Fitriyati, I., Hidayat, A. and Munzil (2017) 'Pengembangan Perangkat Pembelajaran IPA untuk Meningkatkan Kemampuan Berpikir Tingkat Tinggi dan Penalaran Ilmiah Siswa Sekolah Menengah Pertama', Jurnal Pembelajaran Sains, 1(1), pp. 27-34.

Gulo, M. L. (2018) 'Meningkatkan Keterampilan Proses Bagi Siswa Dengan Menggunakan Model Pembelajaran Think Pair Share Pada Mata Pelajaran IPA Kelas IV Sekolah Dasar’, pp. 1-15.

Hasibuan, S. A. (2018) 'Upaya meningkatkan hasil belajar siswa dengan menggunakan model pembelajaran talking stick pada mata pelajaran IPA materi gaya di kelas V MIN Medan Maimun Kelurahan Timbang Deli Kecamatan Medan Amplas'. Universitas Islam Negeri Sumatera Utara.

Naziaha, S. T., Maula, L. H. and Sutisnawati, A. (2020) 'Analisis Keaktifan Belajar Siswa Selama Pembelajaran Daring Pada Masa Covid-19 Di Sekolah Dasar', Jurnal JPSD, 7(2), pp. 109-120.

Retnawati, H. (2015) 'Teknik Pengambilan Sampel_', Ekp, 13(3), pp. 1576-1580.

Sanjaya, D. R. H. W. (2016) Penelitian tindakan kelas. Prenada Media.

Sudjana, N. (2006) penilaian Hasil Proses Belajar Mengajar. Bandung.

V, D. I. K. (2018) 'Volume 6, Nomor 1, 2018', 6. 